\title{
Microfinance: A comparative Study Of Bangladesh and India
}

\author{
Naveen Kumar. $\mathrm{H}^{1}$, Dr. S.J.Manjunath ${ }^{2}$, Srikanth H.S ${ }^{3}$ \\ ${ }^{I}$ (Research Scholar Department Of Business Administration B.N.Bahadur Institute Of Management Sciences \\ University Of Mysore, Mysore, India) \\ ${ }^{2}$ (Associate Professor Department Of Business Administration B.N.Bahadur Institute Of Management Sciences \\ University Of Mysore, Mysore, India) \\ ${ }^{3}$ (Research Scholar Dos In Commerce Shree Nataraja Pg Centre University Of Mysore, Mysore, India)
}

\begin{abstract}
Microfinance is being practiced as a tool to attack poverty the world over. The term "Microfinance" can be defined as "provision of thrift, credit and other financial services and products of very small amounts to the poor in rural, semi- urban or urban areas, for enabling them to raise their income levels and improve living standards". The aim of the paper is to understand whether the institutions are serving their purpose of existence or are these rather becoming profit-making centers. This paper conducts a comparative study between India and Bangladesh, in terms of loan lent by institutes to the customers, clientele, financial sustainability of MFI's Institutions, in order to understand how MFI's in India are performing as against those MFI's in Bangladesh as it is considered to be the originator of Microfinance. The paper discovers that no doubt Indian MFI's are more profitable and operating more efficient than those in Bangladesh.
\end{abstract}

Keywords: Microfinance Institutions, Financial Sustainability, profitability, Clientele.

\section{Evolution of Micro finance}

Microfinance as an industry evolved in all the third world countries almost at the same time span. The world over, it was getting widely recognized that improving income levels of low-income community is essential to improve their well-being - besides the state sponsored welfare programmers. During the 1970s and 1980s, the microenterprise movement led to the emergence of Non- Governmental Organizations (NGOs) that provided small loans for the poor. In 1990s, across the world, a number of these institutions transformed themselves into formal financial institutions in order to access and on-lend funds, thus enhancing their outreach. One of the significant events that helped it gain prominence in the 1970s was through the efforts of Mohammad Yunus, a microfinance pioneer and founder of the Grameena Bank of Bangladesh. In 2006, Prof. Yunus was awarded Nobel Peace prize "for his efforts to create economic and social development from below." In India, many formal financial institutional structures were experimented with - Regional Rural Banks (RRBs), District Central Credit Cooperative Banks (DCCBs), Local Area Banks (LABs), Self-Help Group (SHG) Bank linkage program. All these received mixed success and paralelly, the civil society organizations started feeling the need to offer financial services to the poor. Credit was getting increasingly recognized as an essential tool to break the vicious cycle of poverty. Gradually, Microfinance Institutions emerged in 1990s and 2000s. MFIs today differ in size and reach; some serve a few thousand clients in their immediate geographical area, while others serve hundreds of thousands, even millions, in a large geographical region, through numerous branches.

\section{Microfinance In India}

Microfinance sector has grown rapidly over the past few decades. Nobel Laureate Muhammad Yunus is credited with laying the foundation of the modern MFIs with establishment of Grameen Bank, Bangladesh in 1976. Today it has evolved into a vibrant industry exhibiting a variety of business models. Microfinance Institutions (MFIs) in India exist as NGOs (registered as societies or trusts), Section 25 companies and NonBanking Financial Companies (NBFCs). Commercial Banks, Regional Rural Banks (RRBs), cooperative societies and other large lenders have played an important role in providing refinance facility to MFIs. Banks have also leveraged the Self-Help Group (SHGs) channel to provide direct credit to group borrowers.

With financial inclusion emerging as a major policy objective in the country, Microfinance has occupied centre stage as a promising conduit for extending financial services to unbanked sections of population. At the same time, practices followed by certain lenders have subjected the sector to greater scrutiny and need for stricter regulation. 


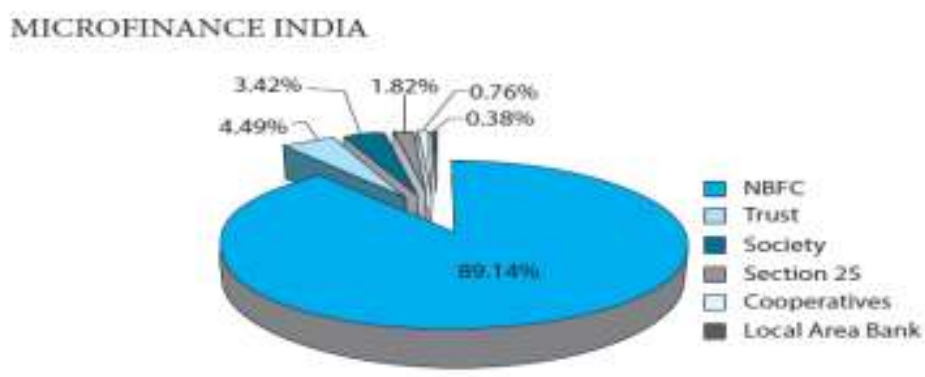

\section{Microfinance In Bangladesh}

Bangladesh has been known as the birthplace of microfinance, and competition has markedly increased during the last decade. Since its inception, microfinance has evolved as an economic development approach to benefit low-income people in rural and urban areas. Bangladesh has one of the longest histories with microfinance. Since various pilot programs and experiments were conducted by Grameen Bank and BRAC, microfinance has undergone continuous improvement in the country.

Now, Bangladesh boasts a large number of well-known microfinance institutions (MFIs) including Grameen Bank, BRAC, and the Association of Social Advancement (ASA). Simultaneously, many smaller MFIs have started operations throughout Bangladesh. As of December 2008, 402 MFIs possess a license from the Microcredit Regulatory Authority (MRA) and 4,236 MFIs have applied for a license.i

As the microfinance market has matured in recent years, competition has increased among major MFIs. Against this backdrop of intense competition, overlapping loan problems among major MFIs and borrowers has emerged as a problem in Bangladesh. While poor people have more choices from which MFIs to borrow money, the number of people who use multiple loans from various MFIs has been increasing. As a result, there are ever more heavily indebted people in Bangladesh, and this is beginning to pose a threat to MFIs and the microfinance industry. Considering how many MFIs operate in Bangladesh, the microfinance market seems to have become saturated.

The object of this study is to analyze the overlapping loan problems based on previous research and interviews the author conducted with ASA borrowers and ASA field staff in Rajshahi and Comilla, Bangladesh in 2009. It will then describe issues caused by those overlapping loan problems. In conclusion, it will recommend measures that the whole microfinance industry in Bangladesh should take to prevent this problem from worsening.

Microfinance is entering into a new and more dynamic phase. The launching of initial public offerings (IPOs), innovations in mobile microfinance services, remittance through microfinance institutions using latest communications technology are the new dimension of microfinance that bring finance - and hope - to the world's least developed countries. Microfinance is rapidly shifting from a niche product to a globally recognized form of finance and becoming more sophisticated and diverse. Bangladesh microfinance sector is mature now and its assets constitute around 3 percent of GDP in 2010. There are four main types of institutions involved in microfinance activities in

Bangladesh:

a) Grameen Bank

b) NGO-MFIs that have received licenses from MRA

c) Commercial and specialized banks

d) Government sponsored microfinance programs (e.g. Through BRDB, cooperative societies and programs under different ministries).

Total outstanding loan of this sector was around Tk. 210 billion (USD 3.2 billion) in December 2010 disbursed among 30 million poor people and savings worth Tk. 160 billion (USD 2.3 billion) which helped them to be self-employed and accelerated overall economic development process of the country.

Microcredit Regulatory Authority (MRA) has been established by the Government of the Peoples' Republic of Bangladesh under the "Microcredit Regulatory Authority Act -2006" to promote and foster sustainable development of microfinance sector through creating an enabling environment for NGO-MFIs in Bangladesh. As the statutory body MRA monitors and supervises microfinance operations of NGO-MFIs. License from the Authority is mandatory to carry out microfinance operations in Bangladesh. MRA publishes statistical information of microfinance sector on a regular basis. The NGO-MFIs provide operational information on a prescribed format twice a year and financial information annually. This publication is based on information provided for the fiscal Year 2010 by 482 NGO-MFIs. 


\section{Micro Finance In Bangladesh}

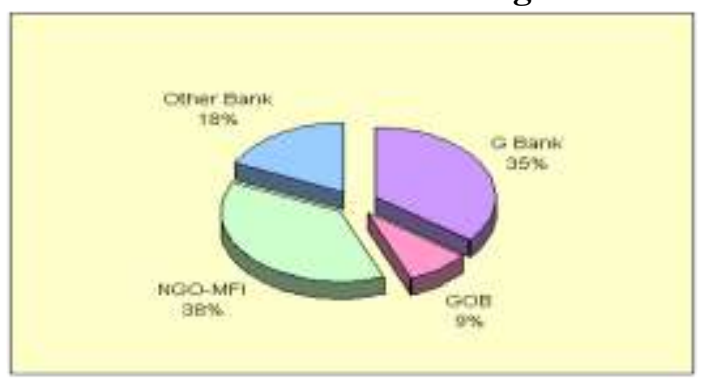

\section{(A) Gross Loan Portfolio}

Gross loan portfolio means the total amount of money lent by institutes to the customers

\section{FIGURE-1}

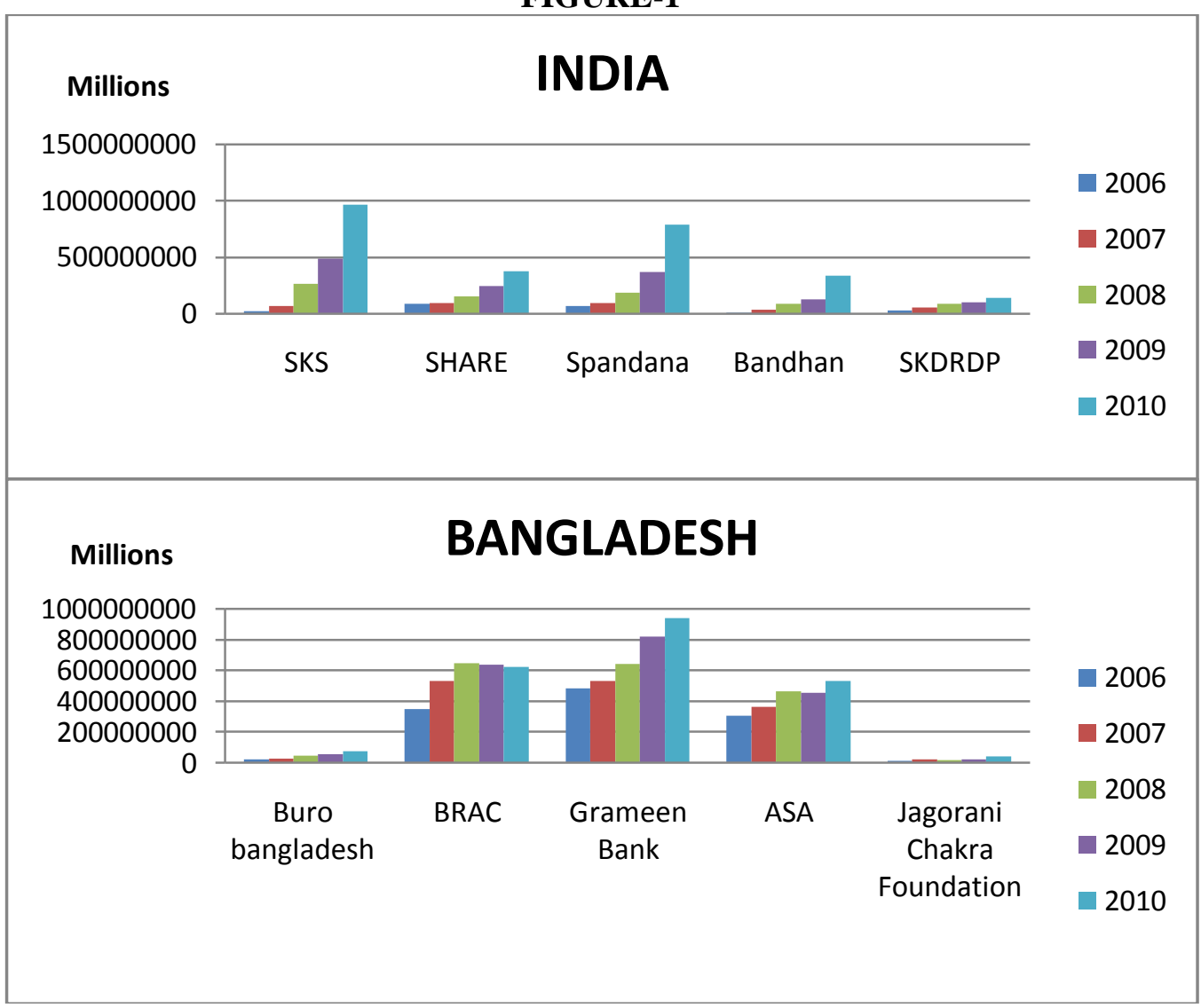

(Source:Mixmarket.org)

Above graphs (Figure.1)clearly depicts that the loan portfolio of Indian MFIs is increasing tremendously year on year as compared to Bangladeshi MFIs. Leaders of MFIs in India has shown a high growth in respect of gross loan portfolio as SKS loan portfolio has grown by more than 900 times in just four year, Spandana loan portfolio rose to around Rs. 800 million from Rs. 100 million from 2006-10, similarly Share"s loan portfolio has quadrupled from 100 to around 400 million in these year.

On the other hand, Bangladesh MFIs leader's loan portfolio is also increasing but the rate of growth is not as such of Indian MFIs. Coming on to the comparison of overall MFIs industry in both the countries, result were similar to that of top institutes in both the countries . 
FIGURE-2

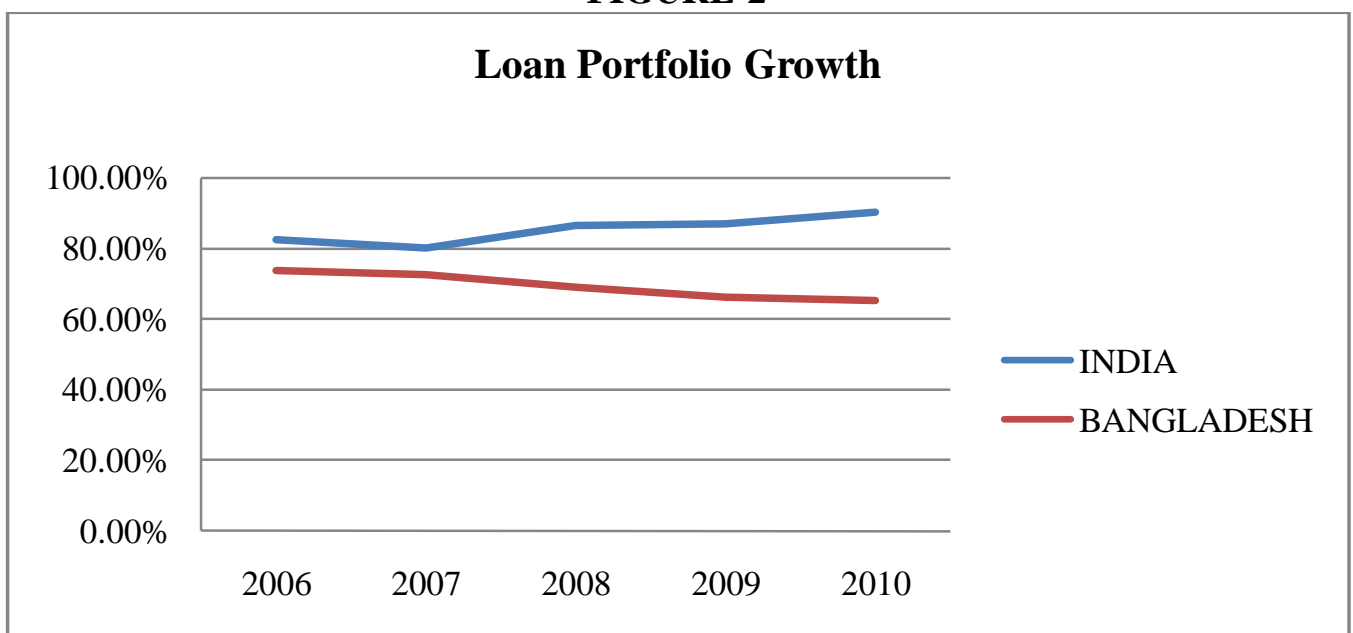

From the above graph(Figure.2) it is evident that the loan portfolio is growing tremendously in India, which has risen to 9.18 times (around 918\%) in 2010 from 2006. Whereas in Bangladesh it has just decline from $73.66 \%$ (2006) to $63.35 \%$ in 2010 around $10.31 \%$ has decline .This might be because of the fact that Serious charges emerged about microfinance borrowers taking on multiple loans and too much debt, coercive collection practices by microfinance staff, and even suicides among borrowers who were unable to meet their payments Moreover the population of India is around 8 times larger than that of bangladesh, therefore the absolute value of loan portfolio has to be higher in India. And the data of last five years is showing that the microfinance activities are penetarating at a good speed in India. (As per CIA, World Factbook India's polpulation (July 2011) : 1,189 million; Bangladesh : 158 million).

FIGURE-3

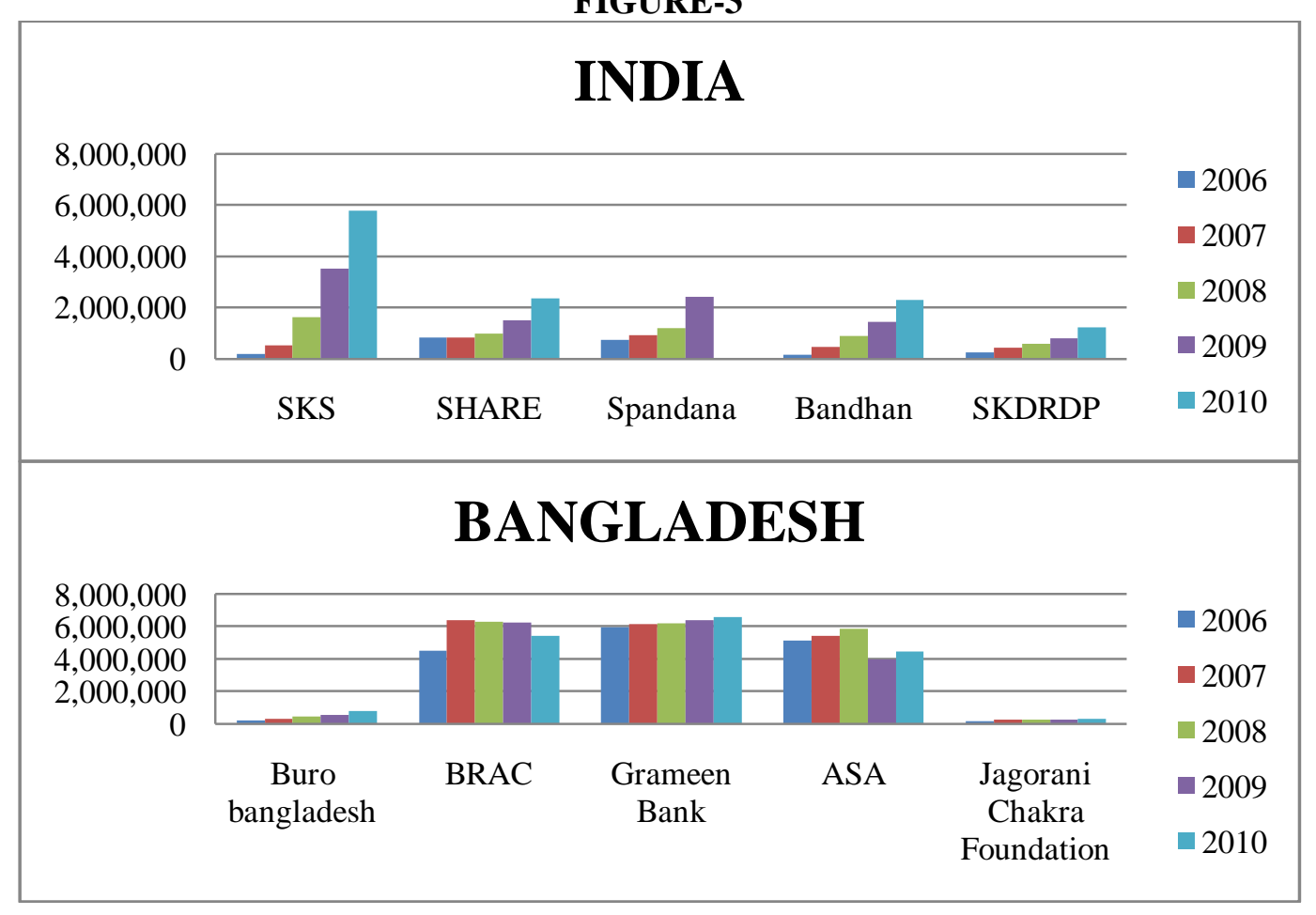

These graph (Figure.3) reflect that the number of active clients of Bangladesh MFIs is much higher than that of Indian MFIs. Bangladeshi MFIs are showing minuscule addition of clients, This might be because of the fact that the concept of microfinance is older in Bangladesh, therefore these institutes may have already reached a mature stage.whereas clientele of Indian MFIs are increasing at a very high speed. Because of such a high rate of growth of Indian MFIs clientele, the gross loan portfolio is growing tremendously. 
FIGURE-4

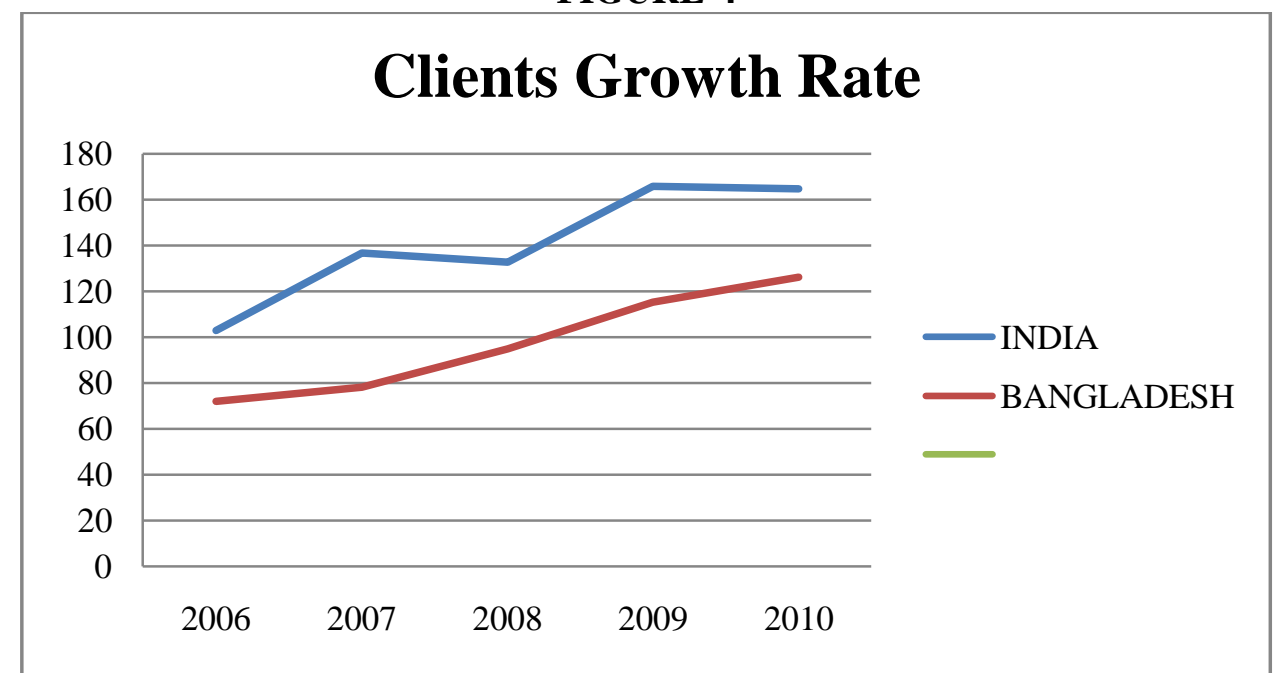

Average Industry figures are also showing same result that the Bangladesh MFIs are not showing any significant growth in client's number whereas the clientele of Indian MFIs are increasing robustly. Apart from this, average loan per borrower/ client 1 has also increased in India from Rs. 106 in 2006 to Rs. 165 in 2010. Similarly in Bangladesh it has increased from Rs. 72 to Rs. 126 in 2010. Therefore if the Indian MFIs are penetrating more and more (increasing clientele) obviously the loan portfolio will grow tremendously.

\section{(B) Cost Of Borrower}

Cost per borrower ratio is very important as it helps to analyse the efficiency of MFIs by determining the average cost of maintaining an active client. Graph below (figure-5) shows the Cost per borrower ratio of MFIs in India and Bangladesh. It is clear that the cost per borrower of institutes in India is increasing, while it has shown downturn in 2010 in SKS ,SHARE and BANDHAN.

\section{FIGURE-5}

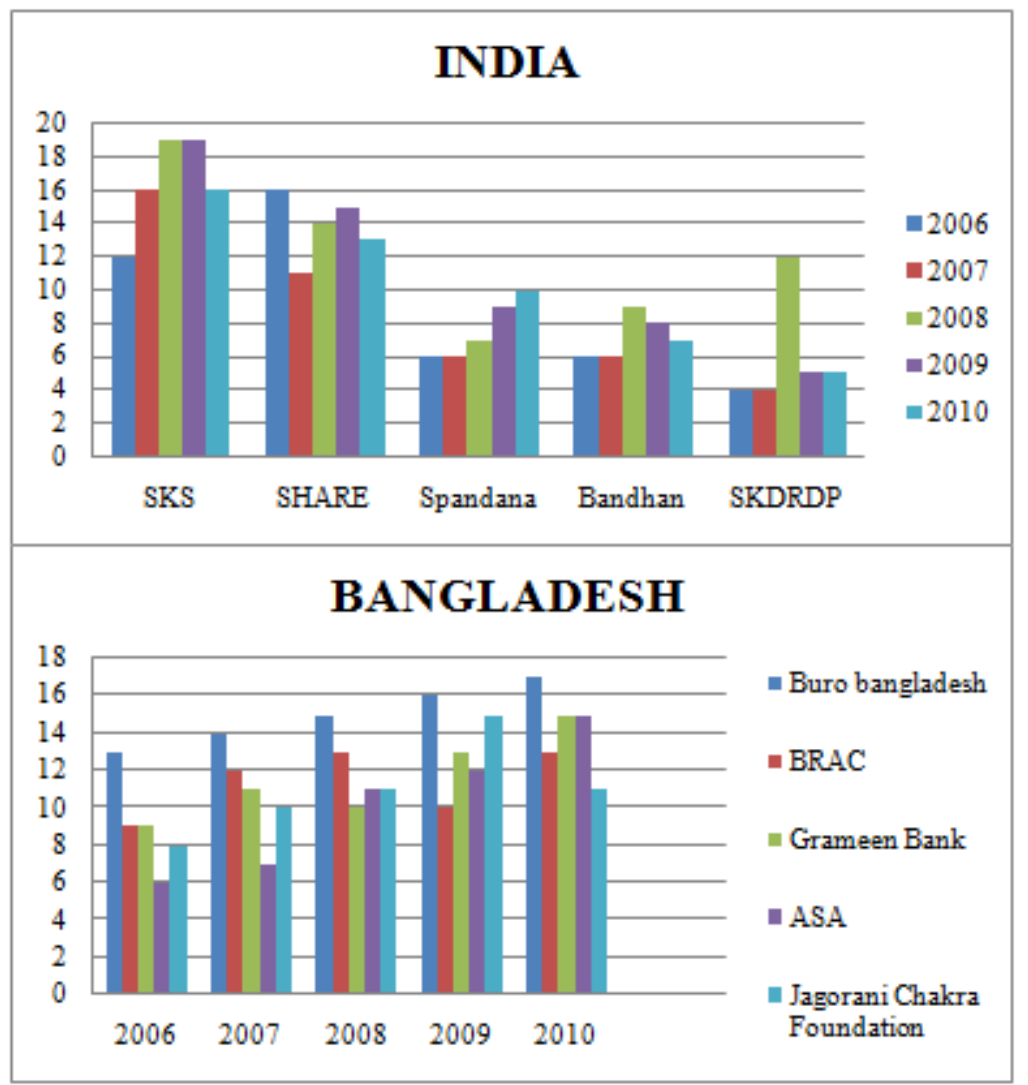


On the hand, although the cost per borrower of MFIs in Bangladesh is showing similar trend but still it is less than Indian MFIs as (Figure .6) below. Whereas on comparing the performance of the overall MFIs industry, it is observed that the cost of borrower's of MFIs in India is much higher than that of MFIs in Bangladesh.

FIGURE-6

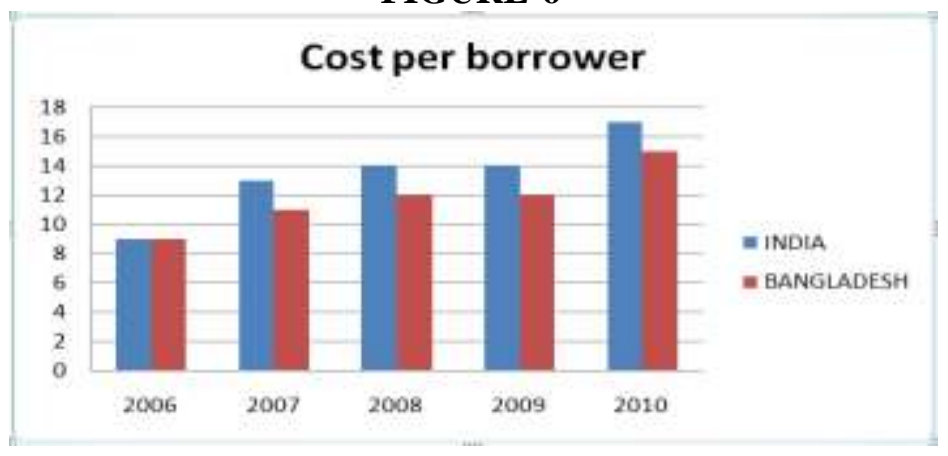

(C) Financial Stability

Upon analysis of the financial ratios of the performance of Indian MFIs with their Bangladeshi counterparts, the comparative scenario upon their working and performance can be woven into following facts and (figure-7).

FIGURE-7

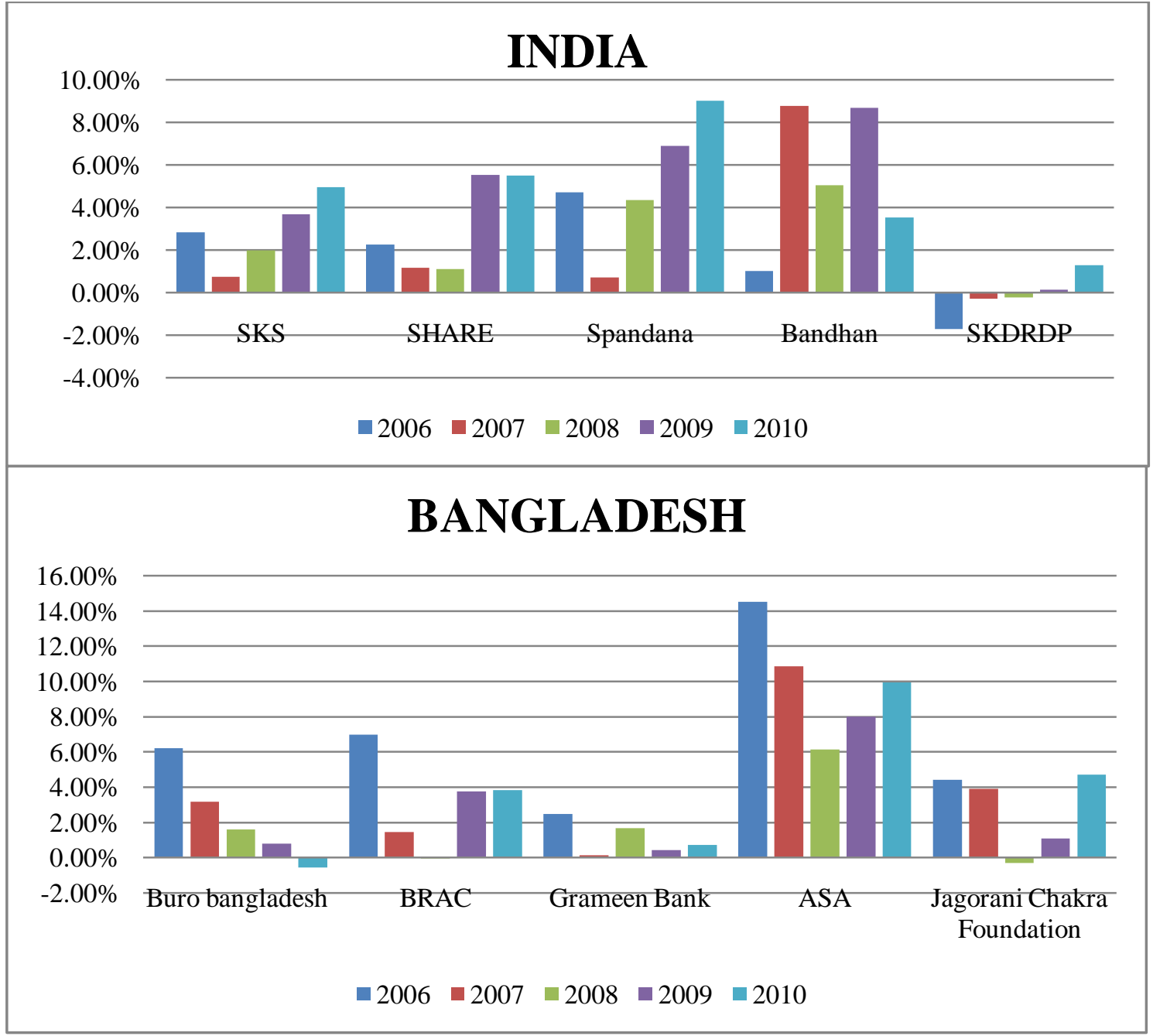

Comparative analysis of Return on Asset (ROA) of top MFIs in India and those in Bangladesh reflects that Indian MFIs are outperforming on the basis of return earned on assets, implying that Indian MFIs are using their assets much efficiently and thus generating higher returns as compared to Bangladesh. 


\section{Industry Average For Roa India And Bangladesh}

\section{FIGURE-8}

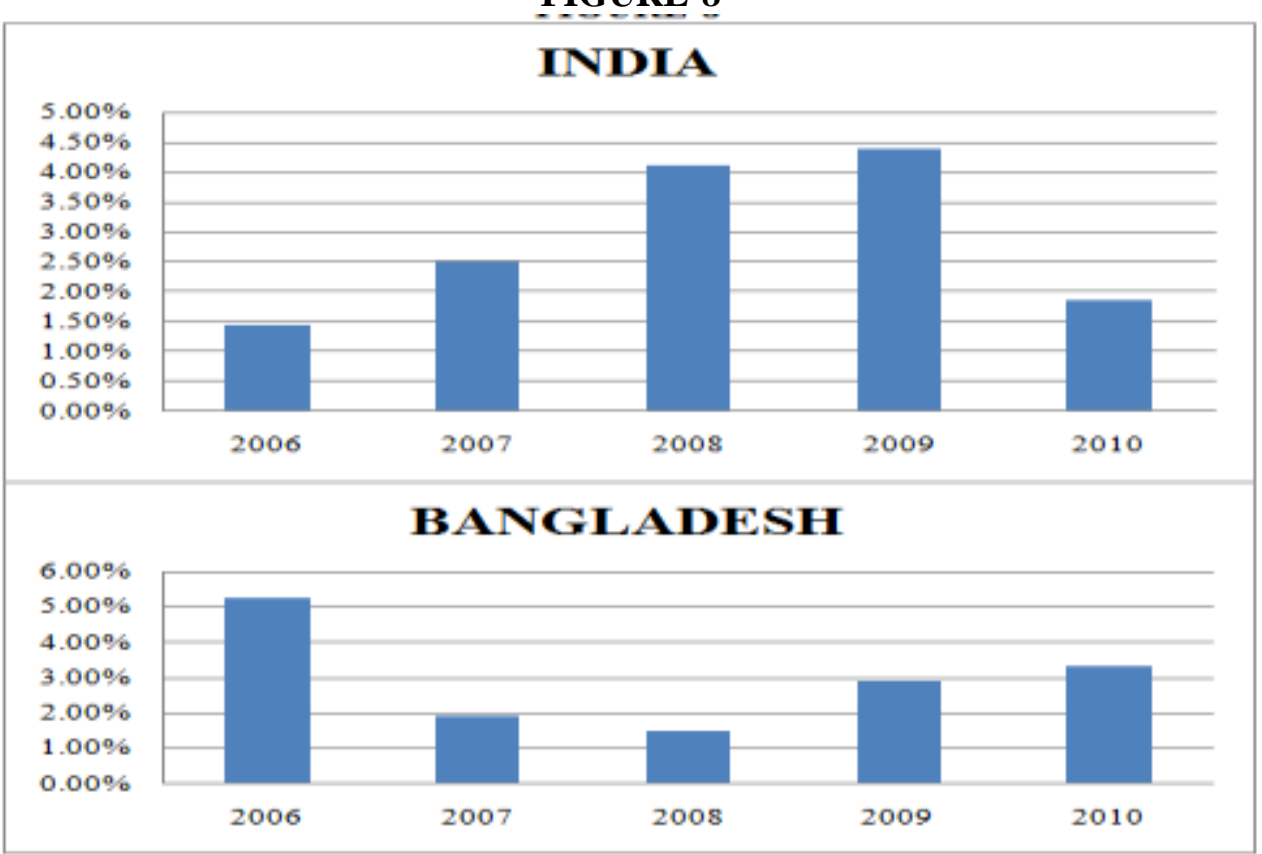

Industry comparison shows that Indian MFIs are showing steady growth in ROA, thus they are making every possible effort to effectively use their assets. While Bangladesh MFIs are undergoing declining ROA although it has increased in 2010 but still it is much lower when compared to Indian MFIs as depicted in figure.8

\section{(D) Yield On Gross Portfolio}

The yield on Portfolio ratio helps to determine the cost/income on the fund raised/distributed. In the context of MFI it is calculated by dividing cash received from interest, fee and commission on the loan by gross loan portfolio. Thus it gives the interest rate at which MFIs is lending loans to people. When comparing this ratio between Indian and Bangladeshi top MFIs, it is observed that although this ratio is increasing of Indian MFIs year on year whereas Bangladesh MFIs are maintaining yield on portfolio somewhat similar since the four years with a slight decrease(Figure.9).

\section{FIGURE-9}

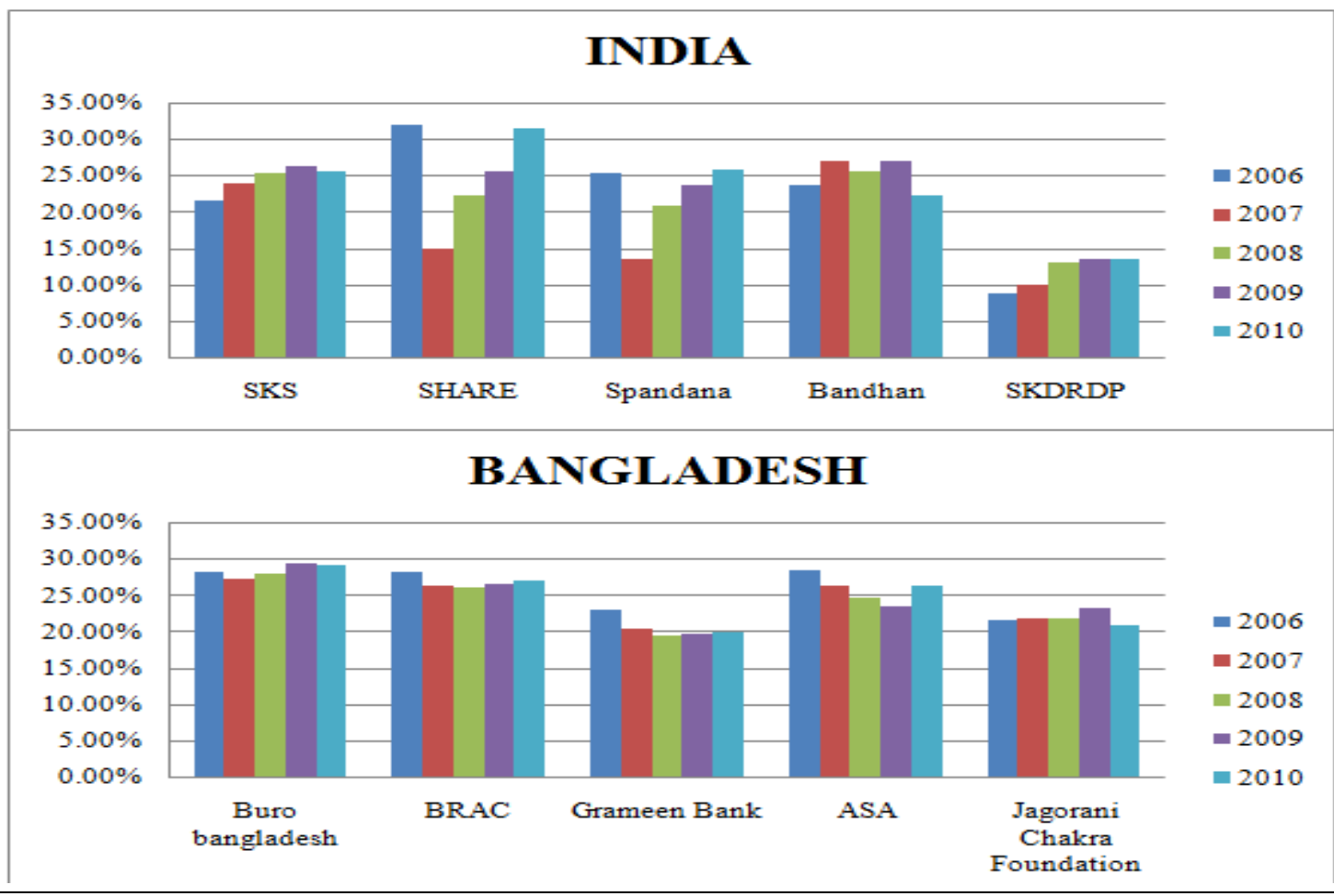

www.iosrjournals.org 
Similarly, upon the comparison of the average yield on a gross portfolio for all the MFIs in India and Bangladesh, it is found that yield is much higher in India, reflecting that the Indian MFIs are charging a much higher rate for loans. In 2006, Yield on a gross portfolio of Indian MFIs was lower than that of Bangladesh MFIs but from then yield on loans provided by Indian MFIs has accelerated and has gone from $16.90 \%$ in 2006 to around $25.25 \%$ in 2009. Thus the interest charged by Indian MFIs has been increased by $8.35 \%$ in just five years. Whereas, Bangladesh MFIs is maintained somewhat similar rates on their loan granted. Apart from these as discussed above ROA of Indian MFIs are increasing y-o-y thus it is clear that Indian MFIs are inclined toward profit motive therefore they are increasing their return by making their operations more efficient and charging higher interest rate on the loans given to the poor people as in (Figure .10).

FIGURE-10

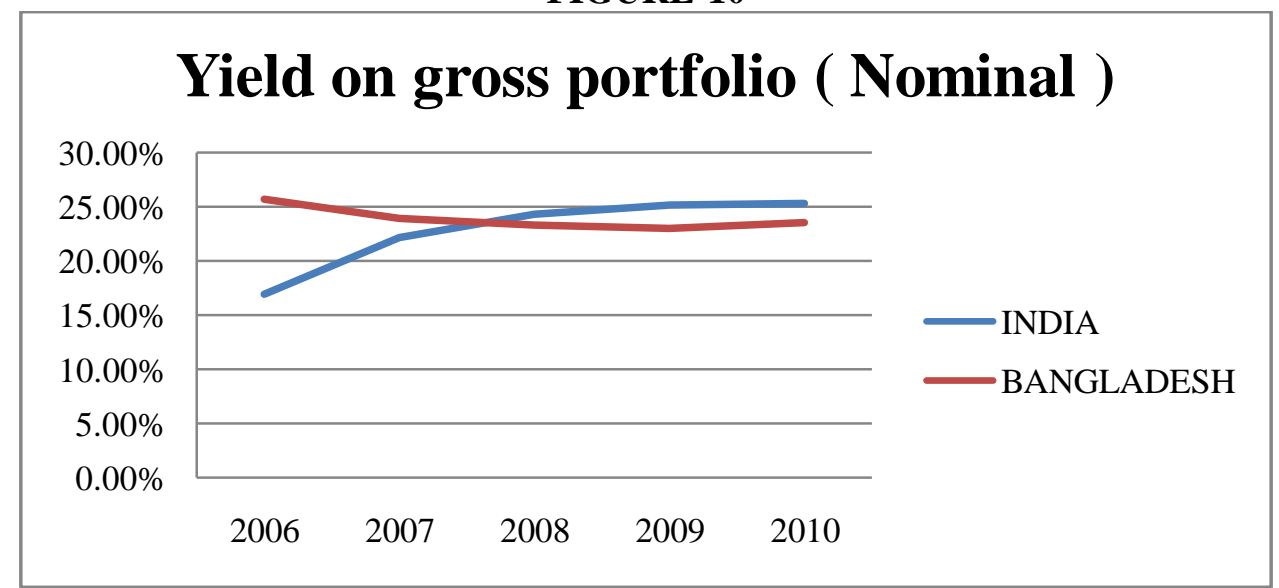

This is a very significant finding which demonstrates that the microfinance industry in India is surely not a ,subprime", thus dispelling the apprehension caused by the statement made by Mr. Reddy.

\section{(E) Return On Equity}

Return on equity is another very significant ratio which helps to calculate the rate of return on average equity for a particular time period. In context of microfinance institutes ROE ratio is generally used as a proxy for commercial viability.

\section{FIGURE-11}

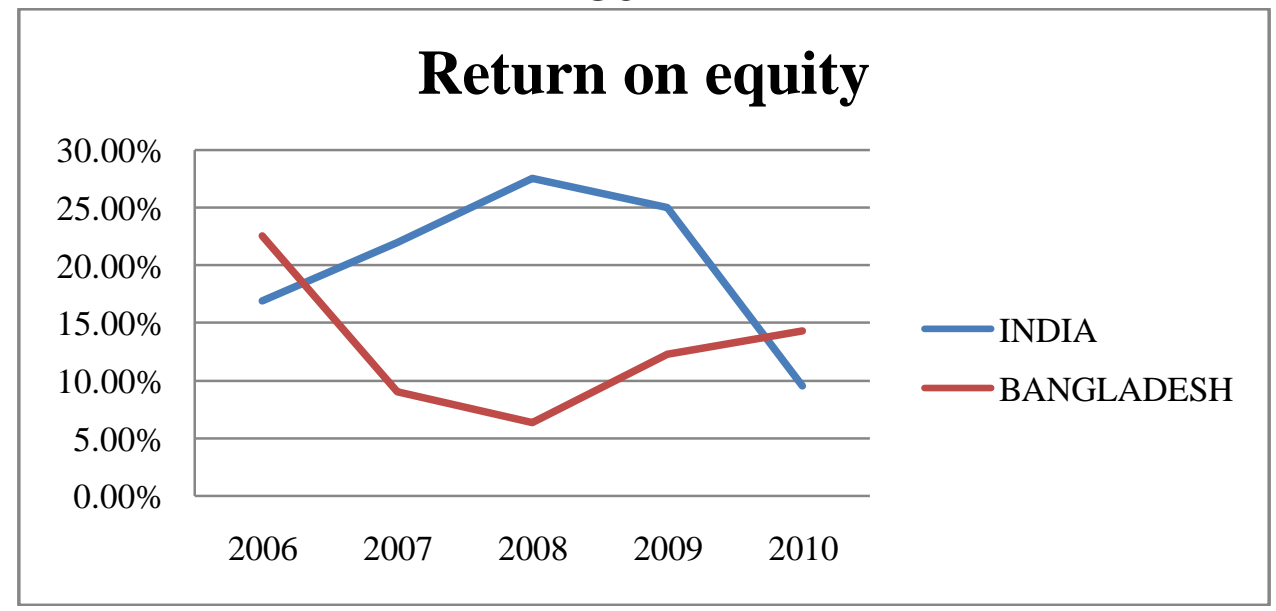

While comparing the ROE of overall microfinance industry of India and Bangladesh, it is observed that the ROE of Indian MFIs is steadily increasing year on year, whereas the ROE of Bangladesh MFIs is decreasing gradually. This substantiates that the MFIs in India are earning higher return on equity and therefore reflecting that they are more inclined towards the commercial motive. On the other hand, Bangladesh MFIs seems to be working for social motive.

\section{Conclusion}

In a country like India, microfinance institutions (MFIs) play a very prominent role in the development of the overall economy. In India microfinance institutions (MFIs) established with the objective of empowering the people to fight against the poverty, building supportive relationships and outreach program to neglected areas. 
But the above analysis has shown that this microfinance institution in India is shifting social institutions to more of profitable venture i.e. Indian MFIs are not as much concentration on the objective of social nature of helping poor in fighting against the poverty but they have become commercialized and focusing on the profit. While saying this, we do not mean that only a lower ROA or ROE essential focus on the social aspects and not the profit aspect of it, but we surely can note that MFIs of India is gradually earning good returns as to maintain a sustainable business model

\section{Reference}

[1] ASA. (1997). Causes of Default in Microcredit: Motivating and Encouraging Enthusiasm Among Group Member s is Essential to Addressing the Causes of Default. Dhaka, Bangladesh: Association for Social Advancement (ASA). Accessed on 14 December 2007.

[2] Basixindia, 2003. Microfinance in india. The paper \& publication. P 1-10. [Online]

[3] Availablehttp://www.bwtp.org/arcm/mfdm/Web\%20Resources/General\%20MF\%20Resources/micro_finan ce_in_india.pdf

[4] CGAP (2002) : Microfinance Consensus Guidelines Viewed on 31 March 2009 (http://www2.cgap.org/gm/document1.9.2787/Guideline_RegSup.pdf)

[5] Economic Times, 2010. Microfinance in India is like subprime lending: Y V Reddy Availableat:http://articles.economictimes.indiatimes.com/2010/11/23/news/27602978_1_priority-sector-lending-sks-microfinancemicrofinance-industry

[6] Financial Data http://www.mixmarket.org/mfi/country/India

[7] Financial Express, 2009. Microfinance world. [Online] Available at: http://indiamicrofinance.com/files/2009/12/MicrofinanceJul-2009.pdf

[8] Fisher. T and M.S. Sriram (2002): "Micro Finance and Livelihoods: The Challenge of BASIX" in Beyond Micr o-Credit Putting Development Back into Micro-Credit, Fisher and Sriram (ed), Vistaar Publications, New Delhi.

[9] Konieczko, 2006. A primer on microfinance. USNews: nation \& world. Available at: http://www.themix.org/sites/default/files/2006_10_13_USNEWS_A\%20primer\%20on\% 20microfinance_0.pdf

[10] Montgomery.H, Weiss. J, 2010. Can commercially oriented microfinance help meet the MDG ?Evidence from Pakistan. World Development. [Online] Available at: http://www.sciencedirect.com.ezproxy.lancs.ac.uk/science? ob=MImg\& imagekey=B6V65197M6R1_cdi=5946\&_user=196517\&_pii=S0305750X10001580\&_origin $=$ search\&_coverDate $=01 \% 2 \mathrm{~F} 31 \% 2 \mathrm{~F} 2011 \&$ sk $=99960$ 9998\&view=c\&wchp=dGLbVzzzSkzS\&md5=18850f1f47269cfefacebda130a25566\&ie=/sdarticle.pdf

[11] Navajas, S., Schreiner, M., Meyer, R.L, Gonzalez-Vega, C. and Rodriguez-Meza, J. (2000).Microcredit and the Poorest of the Poor: Theory and Evidence from Bolivia, World Development 28, 333 - 346.Publications.

[12] Reddy, Y V (2005) : Microfinance: Reserve Bank s Approach, Address at the Microfinance Conference organised by the Indian School of Business, August 6 Reserve Bank of India.Accessed on 31 March 2009 (http://www.rbi.org.in/).

[13] Reddy, Y.V, 2005. Micro-finance: reserve bank s approach. Reserve Bank of India Bulletin.P841846[Online]Availableathttp://www.rbi.org.in/scripts/BS_ViewBulletin.aspx?Id=6913

[14] Sinha, S and F. Sinha (2002): "Sustainability and Development: Evaluating the Performance of Indian Micro-Credit" in Beyond Micro- Credit Putting Development Back into Micro-Credit, Fisher and Sriram (ed), Vistaar Publications, New Delhi.

[15] Srinivasan, N (2009) : Microfinance India State of the Sector Report, 2008 New Delhi: Sage.

[16] Sriram, M.S, Upadhyayula, R.S, n.d. The transformation of the microfinance sector in India. Journal of Microfinance. [E journal] 6 (2). P 89-112. Available at: http://www.iimahd.ernet.in/ mssriram/jmf.pdf

[17] Vonderlack. R.M, Scheiner. M, 2002. Women, microfinance, and savings: lessons andproposals.Developmentinpractice[Online]12(5).Availableat:http://web.ebscohost.com.ezproxy.lancs.ac.uk/ehost/pdfvieer/pdfvie wer?hid=9\&sid=e32168c4-ab50-4843-bf3a-741372f9917e\%40sessionmgr13\&vid=2

[18] Wall Street Journal, 2010.IPO Pits Profit vs. Altruism --- Indian Microlender Sees Scale in Capitalism; Industry Pioneer Has His Doubts; Available at :http:// proquest.umi.com. ezproxy.lancs.ac.uk/pqdweb? did=2076329511 $\&$ sid $=2 \&$ Fmt $=4 \&$ clientId $=14829 \&$ RQT $=309 \&$ VName $=$ PQD 